International Journal of Pharmaceutics \& Pharmacology

EDW $\triangle$ SER

Available Online: https://ijpp.edwiserinternational.com

\title{
Letter to Editor: Steps and Measure to Stop the Spread of COVID-19
}

\section{Mohammed Irfan*}

Clinical Pharmacist/Independent Researcher, Kinapse, Syneos Health Company, Gurugram-122010, Haryana, India

\section{Letter to Editor}

The coronavirus (Covid-19) falls into the category of viruses that may cause numerous symptoms of which the most common ones are fever, tiredness and dry cough. Severe symptoms include lung infection and difficulty in breathing. Elderly people who are having other comorbid diseases such as asthma, diabetes, or heart disease are the most vulnerable towards corona infection [1]. On 29 ${ }^{\text {th }}$ December 2019 in Wuhan city of China, the first case of novel coronavirus was reported. The virus was found to affect the lower respiratory tract of patients. This virus was called 2019 novel coronavirus or the COVID-19 by World Health Organization [2-5]. In December 2019 bunch of patients with pneumonia of unknown cause was linked to local Hunan South China Seafood Market in Wuhan, Hubei Province China. [6]. With sudden outbreak of this virus, the Chinese Center for Disease Control and Prevention (China CDC) sent a team who can join the health authorities of Hubei province and Wuhan city to conduct epidemiological and etiological investigations of this COVID-19. After the investigation WHO confirmed that, the outburst of the coronavirus was associated with the seafood marketplace of Huanan South China, but the spread was not associated with any animal exposure at that time. WHO confirmed COVID19 as a Public Health Emergency, and it became International Concern for almost all countries [7].

\section{Steps to stop the spread of pandemic coronavirus}

The Chief Minister of Delhi, India announced that it is a war with invisible enemy i.e. COVID-19. This war can be won by the formula 'five T plan' - testing, tracing, treatment, teamwork, and tracking and monitoring, to tackle COVID-19. The economy is getting down, and millions of lives are in danger. Most economist believes that it will take months or even years for economic recovery and whole world is heading towards recession. Eradication of this virus requires some hard decision and focused operation in the state of Delhi. The main aim should not be flattening of the curve but to crush the spread of this virus as China did this in Wuhan city, they not only flattened the curve, but they have crushed it. In addition, if we are able to find more information about this virus like, where the virus lurks, how fast it is spreading and how much time this virus is active in the atmosphere, which anti-viral makes it susceptible, we can again re-build our economy without putting additional lives in danger.

If we are able to unite and mobilize then by taking five simple steps, we can eradicate this virus-

1. Create joint command: There should be a chief person who reports straight to the higher authority. He should be in touch with every local councilor to appoint an individual who will be directly reporting to him and provide daily update of his/her area. This will drastically help in pointing out hot spot area in different constituency and that will help in monitoring and controlling the spread of this lethal virus.

2. Arrange millions of diagnostic kits: Testing of each and every people or at least of such individuals who are showing any symptoms is very important. Arranging and producing diagnostic kits in ambient amount is of utmost importance if we want to flatten the curve. Testing of millions of people was the main key factor in controlling the spread of this pandemic by identifying and treating the infected patients in isolation unit in South Korea. Any decision about managing cases will totally depends upon medical assessment and the result of the diagnostic test. If the testing is not done properly, we cannot control the outburst of this pandemic situation.

3. Health care worker who are treating COVID-19 patients should be well equipped with PPE and necessary arrangement to meet any emergency condition: Abundant and continuous deliveries of PPE (personal protective equipment) should be made available to each health worker who are in direct contact with COVID-19 positive patients and 
testing for infection. It is as same as sending a soldier with empty hand to fight in the war, so the health care workers who are treating those patients deserve no less. The government should arrange ventilators and other necessary medication with the utmost need.

4. Classify the people into different category: Initially we want to know who is disease-ridden then following with who is presumed to be infected (i.e. All those people who have manifestation persistent with contagion disease who firstly had there test negative); third category is of those people who has been exposed; fourth, one are those people who is not known to have been infected and did not comes in contact with any COVID 19 virus infected person; and last category comprised of those who has improved from this COVID-19 virus infection and have developed immunity from this virus. We must take an action based on signs, physical investigation, tests (currently using the PCR assays to identify viral RNA), and the most important thing is to find out those people who falls in first four category.

- It is important to admit those people who are having other comorbid conditions and those people are more prone towards this infection.

- Create hospitals by using available convention centers, for taking care of those who are showing mild or moderate disease symptoms and are at low risk.

- Create an isolation ward for all patients that will help in reducing the spread of this virus to other individual.

- Transform guesthouses and create quarantine unit where people kept for under observation from general population for 14 days.

The most important thing is to keep an eye on those group of patients who were before been diseaseridden by the virus and now have recovered and are adequately immune towards the virus. They may help in evolution and validating, and disposition of antibody-based tests. This will prove to be a breakthrough moment in flattening of curve and restarting parts of the economy more quickly and safely.

5. Unite the people to make them aware: In this pandemic, each individual has to play its role. Each individual can support in reducing the risk of exposure and support other individual in this critical time. Health care professionals who are working in the front lines should have PPEs and for this various NGO (Non-Profitable Government organization) can help in providing the same. They can also help in disinfecting their local areas. Wearing of masks at public places by every person should be promoted.

If we all take precautionary measures and determined approach, we can flatten the curve and will also help in recovering our economy. Government should also come forward and help its citizens who belongs to below the poverty line. These steps will shape up our economy when this pandemic will get eradicated. If we are able to follow these steps, we can reduce the number of infected cases and in return we will able to revive our economy once gain. While we struggle to get better of this immediate pandemic, we should take steps to be better prepared to deal with the coronavirus over time. Rather than taking a hard decision, we should make a proper strategy that will help in fighting with this coronavirus. If we act wisely and immediately, we can control the spread of this virus.

\section{References}

1. WMHC. Wuhan Municipal Health and Health Commission's Briefing on the Current Pneumonia Epidemic Situation in Our City. 2020. http://wjw.wuhan.gov.cn/front/web/showDetail/20 19123108989. Accessed 1 Feb 2020.

2. Jahangir MA, Muheem A, Rizvi MF, et al. Coronavirus (COVID-19): History, Current Knowledge and Pipeline Medications. Int J Pharm Pharmacol 2020; 4: 140.

3. Li Q, Guan X, Wu P, Wang X, Zhou L, Tong Y, et al. Early transmission dynamics in Wuhan, China, of novel coronavirus-infected pneumonia. N Engl J Med. 2020.

4. CDC. 2019 Novel coronavirus, Wuhan, China. 2020. https://www.cdc.gov/coronavirus/2019nCoV/summary.html. Accessed 1 Feb 2020.

5. WHO. Novel Coronavirus-China. 2020. https://www.who.int/csr/don/12-january-2020novel-coronavirus-china/en/. Accessed 1 Feb 2020.

6. Zhu N, Zhang D, Wang W, Li X, Yang B, Song J, et al. A novel coronavirus from patients with pneumonia in China, 2019. N Engl J Med. 2020.

7. WHO. Statement on the second meeting of the International Health Regulations (2005) Emergency Committee regarding the outbreak of novel coronavirus (2019-nCoV). 2020. https://www.who.int/news-room/detail/30-012020-statement-on-the-second-meeting-of-theinternational-health-regulations-(2005)emergency-committee-regarding-the-outbreak-ofnovel-coronavirus-(2019-ncov). Accessed 1 Feb 2020. 
Citation: Irfan M. Letter to Editor: Steps and Measure to Stop the Spread of COVID-19. Int J Pharm Pharmacol 2020; 4: 142. doi: 10.31531/2581-3080.1000142

*Corresponding author: Mr. Mohammed Irfan, Clinical Pharmacist/Independent Researcher, Kinapse, Syneos Health Company, Gurugram-122010, Haryana, India; E-mail: irfan.mohd9@gmail.com
Article Info

Received 09 April 2020

Revised 10 April 2020

Published 13 April 2020

Copyright: (02020 Irfan M. This article is distributed under the terms of the Creative Commons Attribution 4.0 International License (http://creativecommons.org/licenses/by/4.0/), which permits unrestricted use, distribution, and reproduction in any medium, provided you give appropriate credit to the original author(s) and the source, provide a link to the Creative Commons license, and indicate if changes were made. 